\title{
EVALUATION OF NITRATE DESTRUCTION METHODS
}

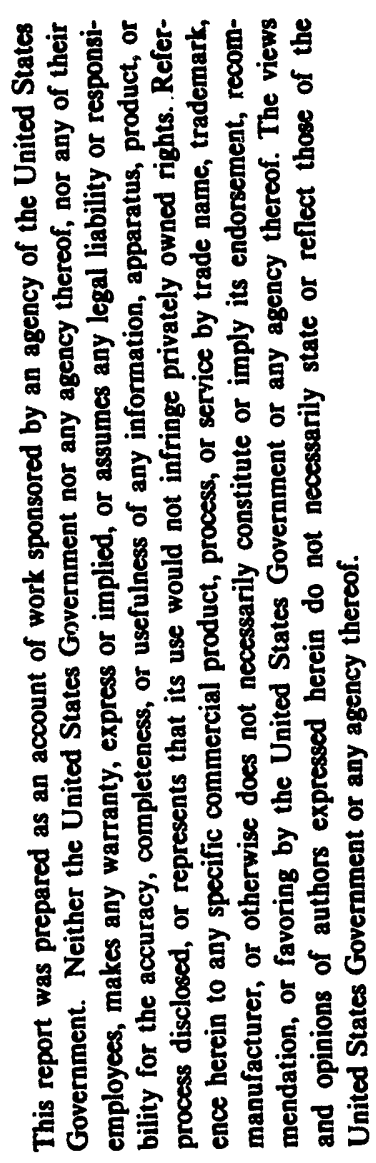

\author{
P. A. Taylor \\ Oak Ridge National Laboratory \\ Oak Ridge, Tennessee 37831-6044 \\ D. E. Kurath \\ R. Guenther \\ Pacific Northwest Laboratories \\ Richland, Washington 99352 \\ March 30, 1993 \\ Prepared by \\ Chemical Technology Division \\ Oak Ridge National Laboratory \\ Prepared for the U.S. DEPARTMENT OF ENERGY \\ OFFICE: OF TECHNOLOGY DEVELOPMENT \\ Washington, D.C. 20585 \\ Prepared by the \\ OAK RIDGE NATIONAL LABORATORY \\ Oak Ridge, Tennessee 37831-6285 \\ managed by \\ MARTIN MARIETTA ENERGY SYSTEMS, INC. \\ for the \\ U.S. DEPARTMENT OF ENERGY \\ under contract DE-AC05-84OR21400
}




\section{CONTENTS}

Page

LIST OF FIGURES $\ldots \ldots \ldots \ldots \ldots \ldots \ldots \ldots \ldots \ldots \ldots \ldots \ldots \ldots \ldots \ldots$

LIST OF TABLES $\ldots \ldots \ldots \ldots \ldots \ldots \ldots \ldots \ldots \ldots \ldots \ldots \ldots \ldots$

EXECUTIVE SUMMARY $\ldots \ldots \ldots \ldots \ldots \ldots \ldots \ldots \ldots \ldots \ldots \ldots \ldots \ldots$

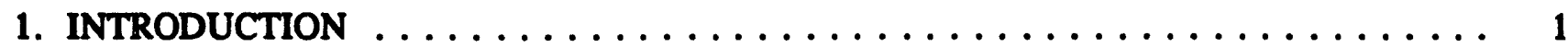

2. COMPOSITION OF NITRATE-CONTAINING MIXED WASTES $\ldots \ldots \ldots \ldots \ldots$

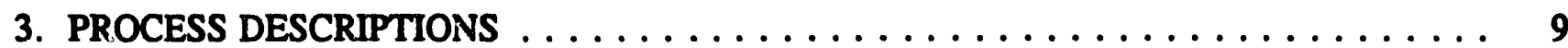

3.1 NITRATE TO AMMONIA AND CERAMIC (NAC) PROCESS $\ldots \ldots \ldots \ldots \ldots \ldots$

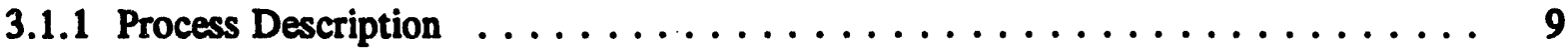

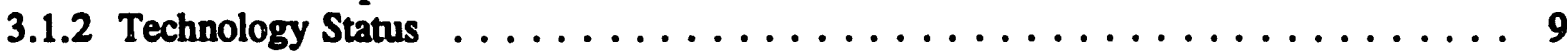

3.1 .3 Advantages ............................... 11

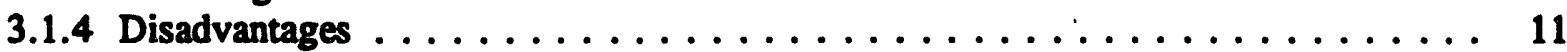

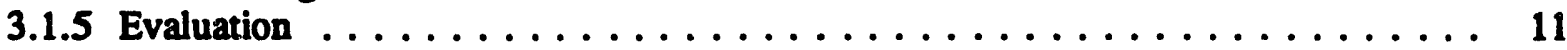

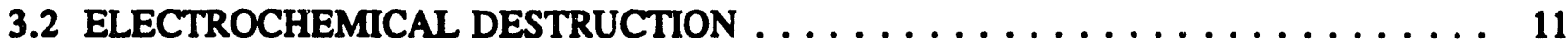

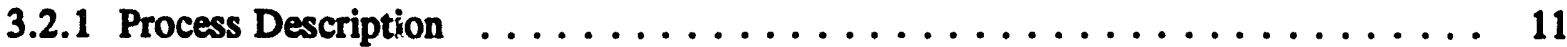

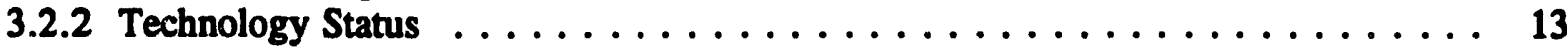

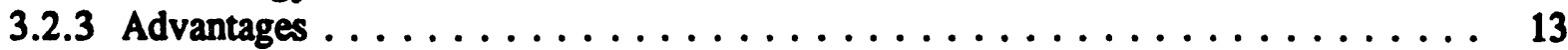

3.2 .4 Disadvantages . . . . . . . . . . . . . . . . . . . . . 14

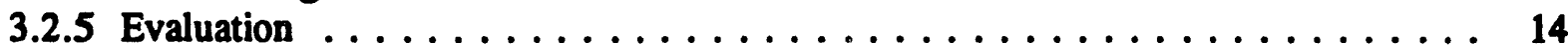



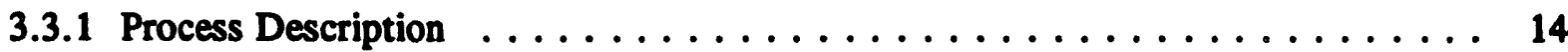

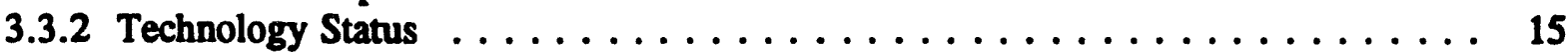

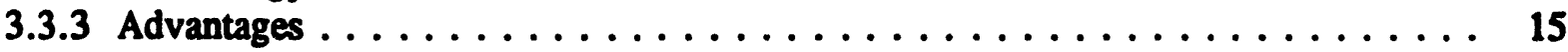

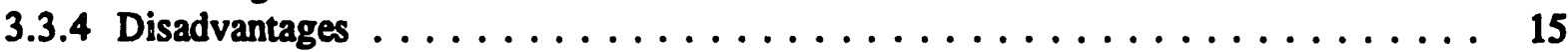

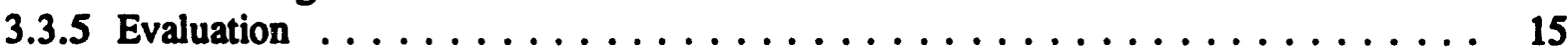

3.4 CHEMICAL REDUCTION $\ldots \ldots \ldots \ldots \ldots \ldots \ldots \ldots \ldots \ldots \ldots$

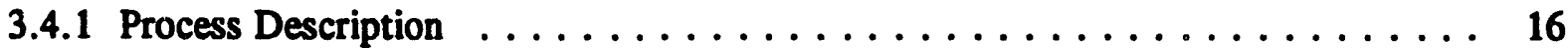

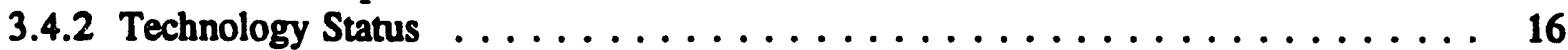

3.4 .3 Advantages . . . . . . . . . . . . . . . . . . . . . . 17

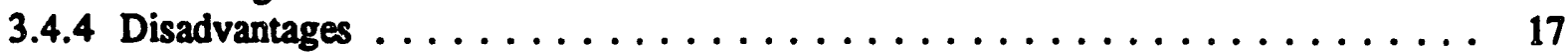

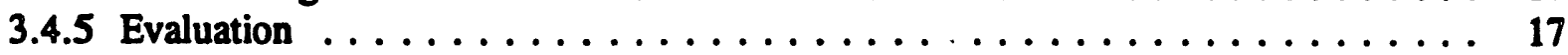

3.5 HYDROTHERMAL PROCESS . . . . . . . . . . . . . . . . . . . 17

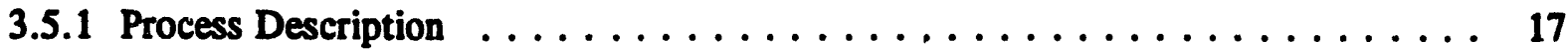

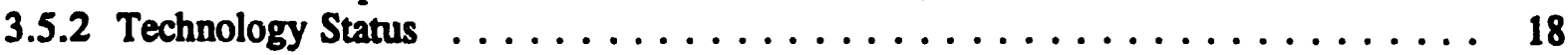

3.5 .3 Advantages . . . . . . . . . . . . . . . . . . . . . 18

3.5 .4 Disadvantages ............................ 18

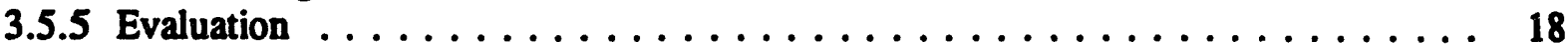

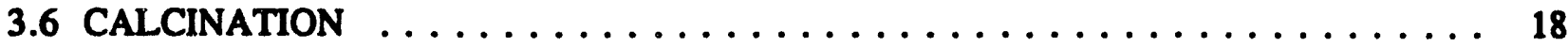

3.6 .1 Process Description $\ldots \ldots \ldots \ldots \ldots \ldots \ldots$ 


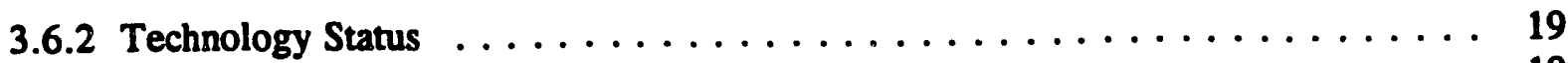

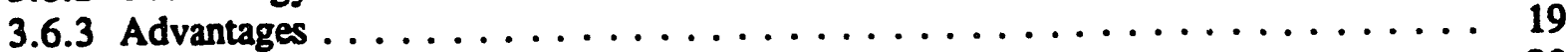

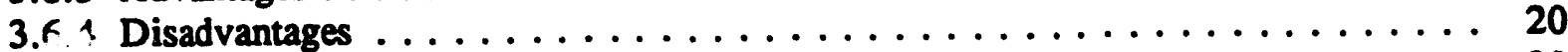

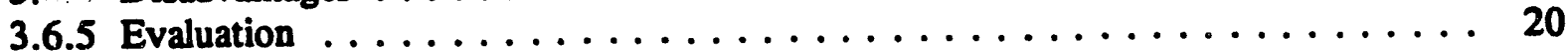

7. SUMMARY $\ldots \ldots \ldots \ldots \ldots \ldots \ldots \ldots \ldots \ldots \ldots \ldots \ldots \ldots \ldots \ldots \ldots \ldots \ldots \ldots$

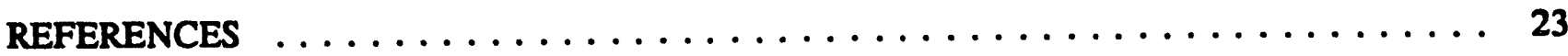




\section{LIST OF FIGURES}

\section{Figure}

Page

1 Flow diagram for nitrate to ammonia and ceramic process $\ldots \ldots \ldots \ldots \ldots \ldots$

2 Destruction cell used to reduce nitrates . . . . . . . . . . . . . . . . . 12 


\section{LIST OF TABLES}

Table

Page

1 Composition of ORNL Low-Level Liquid Waste, Melton Valley Storage Tank (MFST) Supernate . . . . . . . . . . . . . . . . . . . . 4

2 Composition of SRP High-Level Waste Tank Supernate . . . . . . . . . . . . . . 5

3 Composition of Hanford Plant High-Level Waste Tank Supernate . . . . . . . . . . . . 6

4 Composition of INEL High-Level Waste Tank Supernate $\ldots \ldots \ldots \ldots \ldots \ldots \ldots$

5 Composition of RFP Nitrate Salt Waste $\ldots \ldots \ldots \ldots \ldots \ldots \ldots \ldots \ldots$ 


\section{EXECUTIVE SUMMARY}

A wide variety of high nitrate-concentration aqueous mixed [radioactive and Resource Conservation and Recovery Act (RCRA) hazardous] wastes are stored at various U.S. Department of Energy (DOE) facilities. These wastes will ultimately be solidified for final disposal, s'though the waste acceptance criteria for the final waste form is still being determined. Because the nitrates in the wastes will normally increase the volume or reduce the integrity of all of the waste forms under consideration for final disposal, nitrate destruction before solidification of the waste will generally be beneficial. This report describes and evaluates various technologies that could be used to destroy the nitrates in the stored wastes. This work was funded by the Department of Energy's Office of Technology Development, through the Chemical/Physical Technology Support Group of the Mixed Waste Integrated Program. All the nitrate destruction technologies will require further development work before a facility could be designed and built to treat the majority of the stored wastes. Several of the technologies have pirticularly attractive features: the nitrate to ammonia and ceramic (NAC) process produces an insoluble waste form with a significant volume reduction, electrochemical reduction destroys nitrates without any chemical addition, and the hydrothermal process can simultaneously treat nitrates and organics in both acidic and alkaline wastes. These three technologies have been tested using lab-scale equipment and surrogate solutions. At their current state of development, it is not possible to predict which process will be the most beneficial for a particular waste stream.

It is recommended that development work continue on the NAC, electrochemical destruction and hydrothermal processes. More information is needed on the capabilities and potential problems of these processes before a reasonable decision can be made on which would be the best for treating a particular waste stream. Also, the overall system requirements for radioactive waste disposal, and in particular the waste acceptance criteria for the final waste form, will need to be finalized before a determination can be made on whether nitrate destruction is required, as well as providing criteria for comparing the various nitrate destruction processes. The development work should include pilot-scale tests to further define the operating limits, through-puts, required process/safety controls and economics of the processes, and small-scale tests on actual waste solutions to identify any potential problems caused by minor waste constituents. 


\section{INTRODUCTION}

A wide variety of nitrate-containing aqueous mixed (radioactive and Resource Conservation and Recovery Act (RCRA) hazardous] wastes are produced or stored at various DOE facilities. These wastes generally have very high concentrations of nitrates (either sodium nitrate or nitric acid) and high levels of radionuclides. The RCRA constituents typically include heavy metals, solvents or both. These wastes will ultimately be solidified for final disposal, although the final methods and criteria for solidification and disposal are still being developed. Because the nitrates in the waste will generally increase the volume or reduce the integrity of all of the waste forms that have been proposed for ultimate disposal, nitrate destruction prior to solidification of the waste will normally be beneficial, although the cost-benefit relationship for nitrate destruction is not yet certain. Nitrates are also a concern as a source of groundwater contamination. In addition, high levels of nitrates will increase ruthenium volatilization during any high-temperature processing of the waste, such as calcination or vitrification.

This report describes the various technologies that have been proposed for destroying nitrates in aqueous wastes and evaluates the potential of each for treating the mixed wastes currently stored at DOE facilities. The technologies were identified from literature searches and from an announcement printed in the Commerce Business Daily soliciting information. Various methods exist for separating nitrates from waste solutions (as opposed to destroying the nitrates), including evaporation (acid wastes only), electrochemical ion exchange, and electrodialysis. Separation methods are being examined at the Rocky Flats Plant (RFP) for recovering nitric acid for reuse. These methods may be desirable for removing nitrates from mixed wastes if a use can be found for the recovered nitric acid; however, separation technologies are not evaluated in this report. 


\section{COMPOSITION OF NITRATE-CONTAINING MIXED WASTES}

Nitrate-containing aqueous mixed wastes are generated and stored at many U.S. Department of Energy (DOE) facilities. Examples of the composition of these wastes are shown below (Tables 1-5). The wastes stored at the Hanford Site, Oak Ridge National Laboratory (ORNL), and the Savannah River Plant (SRP) are all high-nitrate-concentration alkaline solutions. The ORNL waste has the highest concentration of potassium, while the Hanford site waste has the highest concentration of total organic carbon. The SRP waste has the highest sodium and nitrite concentrations. The Idaho National Engineering Laboratory (INEL) waste is acidic, has a very high nitrate concentration, and contains significant concentrations of chromium and mercury. The waste at RFP is much more dilute; it is currently dried and then mixed with cement before storage. The composition data for Hanford, ORNL, and RFP are overall averages, while the data for INEL and SRP are for one specific tank; however, at all of the sites, the waste composition varies widely among tanks. The waste composition results listed in Tables 1-5 were chosen to give as wide a variation as possible among the wastes at the various sites.

Generally, the nitrate destruction processes are not particularly sensitive (or else have not been tested sufficiently to know if they are sensitive) to feed composition. However, in most cases, a significant difference in process performance or pretreatment requirements exists between acidic and alkaline feeds. 
Table 1. Composition of ORNL Low-Level Liquid Waste Melton Valley Storage Tank (MVST) Supernate (Average composition of 10 tanks)

$$
\begin{aligned}
& \text { Volume }=830,000 \mathrm{~L} \\
& \text { Density }=1.23 \mathrm{~g} / \mathrm{mL} \\
& \text { pH }=12.5
\end{aligned}
$$

\begin{tabular}{|c|c|c|}
\hline \multirow[b]{2}{*}{ Contaminant } & \multicolumn{2}{|c|}{ Concentration } \\
\hline & $(g / L)$ & $(\mathrm{Bq} / \mathrm{L})$ \\
\hline Nitrate & 270 & \\
\hline Sodium & 88 & \\
\hline Potassium & 24 & \\
\hline Carbonate & 6.9 & \\
\hline Calciem & 3.4 & \\
\hline Chloride & 2.9 & \\
\hline Magnesium & 0.7 & \\
\hline Total Organic Carbon & 0.6 & \\
\hline Uranium & 0.2 & \\
\hline${ }^{137} \mathrm{Cs}$ & & $4.8 \mathrm{E} 8$ \\
\hline${ }^{\infty} \mathrm{Sr}$ & & 4.1E7 \\
\hline${ }^{134} \mathrm{Cs}$ & & 5.0E6 \\
\hline${ }^{\infty} \mathrm{Co}$ & & 3.4E6 \\
\hline${ }^{105} \mathrm{Ru}$ & & 8.7E5 \\
\hline Gross alpha & & 3.3ES \\
\hline${ }^{14} \mathrm{C}$ & & $1.9 \mathrm{ES}$ \\
\hline
\end{tabular}

Source: M. B. Sears, et al., Sampling and Aralysis of Radioactive Liquid Wastes and Sludges in the Melton Valley and Evaporator Facility Storage Tanks at ORNL, ORNL/TM-11652, Martin Marietta Energy Systems, Inc., Oak Ridge National Laboratory, September 1990. 
Table 2 Composition of SRP High-Level

Waste Tank Supernate

(Results from Tank No. 2, F-Area)

1.

Volume $=380,000,000 \mathrm{~L}$

Density $=1.41 \mathrm{~g} / \mathrm{mL}$

$\mathrm{pH}=14.5$

\begin{tabular}{lcc}
\hline \multirow{2}{*}{ Contaminant } & \multicolumn{2}{c}{ Concentration } \\
\cline { 2 - 3 } Sodium & $(\mathrm{g} / \mathrm{L})$ & $(\mathrm{Bq} / \mathrm{L})$ \\
\hline Nitrate & 214 & \\
Nitrite & 149 & \\
Hydroxide & 133 & \\
Ai.minum & 76.5 & \\
Carbonate & 18.9 & \\
Phosphate & $<6.0$ & \\
Chloride & 3.8 & \\
Sulfate & 2.1 & \\
Chromium & 1.9 & \\
& 0.2 & \\
${ }^{137}$ Cs & & $1.3 \mathrm{E} 11$ \\
${ }^{13}$ Cs & & $5.0 \mathrm{E} 9$ \\
${ }^{106} \mathrm{Ru}$ & & $2.3 \mathrm{E} 9$ \\
${ }^{90} \mathrm{Sr}$ & & $1.7 \mathrm{E} 6$ \\
Gross alpha & & $<.0 \mathrm{E} 3$ \\
\hline
\end{tabular}

Source: R. S. Ondrejcin, Chemical Compositions of Supernates Stored in SRP High Level Waste Tanks, DP-1347/UC-70, E. I. du Pont de Nemours \& Co., Savannah River Laboratory, August 1974. 
Table 3. Composition of Hanford Plant High-Level Waste Tank Supernate

$$
\begin{aligned}
& \text { Volume }=600,000,000 \mathrm{~L} \\
& \text { Density } \approx 1.3 \mathrm{~g} / \mathrm{mL} \\
& \mathrm{pH} \approx 14
\end{aligned}
$$

\begin{tabular}{|c|c|c|}
\hline \multirow[b]{2}{*}{ Contaminant } & \multicolumn{2}{|c|}{ Concentration } \\
\hline & $(g / L)$ & $(\mathrm{Bq} / \mathrm{L})$ \\
\hline Nitrate & 183 & \\
\hline Sodium & 115 & \\
\hline Hydroxide & 32 & \\
\hline Nitrite & 23 & \\
\hline Phosphate & 8.0 & \\
\hline Carbonate & 3.9 & \\
\hline Sulfate & 2.8 & \\
\hline Total Organic Carbon & 2.6 & \\
\hline Aluminum & 2.3 & $\cdot$ \\
\hline Potassium & 1.8 & \\
\hline Fuoride & 1.3 & \\
\hline Chloride & 0.06 & \\
\hline${ }^{237} \mathrm{Cs}$ & & $9.4 \mathrm{E} 8$ \\
\hline${ }^{2} \mathrm{Sr}$ & & 3.1E7 \\
\hline Tc & & 9.4E5 \\
\hline${ }^{211} \mathrm{Am}$ & & $2.5 \mathrm{E} 5$ \\
\hline${ }^{20} \mathrm{Pu}$ & & $2.5 \mathrm{E} 4$ \\
\hline
\end{tabular}

Volume and concentration data is based on dissolving the existing solid salt cake and supernate into a $5 M$ sodium solution. Sounce: Final Environmental Impact Statement: Disposal of Hanford Defense High-Level, Transuranic, and Tank Wastes, DOE/EIS-0113, December 1987. 
Table 4. Composition of INEL High-Level Waste Tank Supernate (Results from Tank WM-183)

$$
\begin{aligned}
& \text { Volume }=7,500,000 \mathrm{~L} \\
& \text { Density }=1.22 \mathrm{~g} / \mathrm{mL} \\
& \mathrm{pH} \approx 0.2
\end{aligned}
$$

\begin{tabular}{|c|c|c|}
\hline \multirow[b]{2}{*}{ Contaminant } & \multicolumn{2}{|c|}{ Concentration } \\
\hline & $(g / L)$ & $(\mathrm{Bg} / \mathrm{L})$ \\
\hline Nitrate & 279 & \\
\hline Sodium & 17.9 & \\
\hline Aluminum & 14.0 & \\
\hline Potassium & 3.9 & \\
\hline Iron & 3.0 & \\
\hline Hydrogen ion & 1.8 & \\
\hline Calcium & .6 & \\
\hline Fluoride & 0.8 & \\
\hline Chromium & 0.7 & \\
\hline Mercury & 0.6 & \\
\hline${ }^{27} \mathrm{Cs}$ & & 9.9E9 \\
\hline${ }^{n s r}$ & & 8.2E9 \\
\hline${ }^{25} \mathrm{Eu},{ }^{15 S} \mathrm{Eu}$ & & $1.3 E 8$ \\
\hline${ }^{140} \mathrm{Ce}$ & & 8.7E7 \\
\hline${ }^{\infty} \mathrm{Co}$ & & $1.8 \mathrm{E} 6$ \\
\hline
\end{tabular}

Sounce: Curis Kent, Idabo National Engineering Laboratory, Idabo Falk, ID, percosal communication to P. A. Taylor, Oak Ridge National Laboratory, Oak Ridge, Tenn., Feb. 4, 1993. 
Table 5. Composition of RFF

Nitrate Salt Waste

Volume $=23,000,000$ Lyear

Density $\approx 1.01 \mathrm{~g} / \mathrm{mL}$

pH - acidic

\begin{tabular}{lll}
\hline & \multicolumn{2}{c}{ Concentration } \\
\cline { 2 - 3 } Contaminant & $(\mathrm{g} / \mathrm{L})$ & $(\mathrm{Bq} / \mathrm{L})$ \\
\hline Nitrate & 3.1 & \\
Sodium & 1.6 & \\
Chloride & 1.4 & \\
Sulfate & 1.4 & \\
Potassium & 1.1 & \\
Carbonate & 0.7 & \\
Calcium & 0.5 & \\
Fluoride & 0.3 & 500 \\
Iron & 0.3 & \\
& & \\
Plutonium (total) & & \\
\hline
\end{tabular}

Sounce: A. Faucet, Rocky Flats Plant, Golden, Colorado, personal communication to P. A. Taylor, Oak Ridge National Laboratory, Oak Ridge, Tenn., March 24, 1993. 


\section{PROCESS DESCRIPTIONS}

\subsection{NITRATE TO AMMONIA AND CERAMIC (NAC) PROCESS}

\subsubsection{Process Description}

The NAC process involves the chemical reduction of nitrate ions to ammonia by powdered aluminum. The aluminum is converted to aluminum hydroxide and sodium aluminate, as shown in the following stoichiometric reaction:

$$
3 \mathrm{NaNO}_{3}+8 \mathrm{Al}+12 \mathrm{H}_{2} \mathrm{O} \rightarrow 3 \mathrm{NH}_{3} \mathrm{t}+5 \mathrm{Al}(\mathrm{OH})_{3}+3 \mathrm{NaAlO}_{2}
$$

Small-scale batch tests using simulated ORNL Melton Valley Storage Tank (MVST) supernate waste and Hanford High-Level Waste (3 to $6 \mathrm{M} \mathrm{NO}_{3}{ }^{-}$) have shown that approximately twice the theoretical amount of aluminum is required to reduce essentially all of the nitrate to ammonia. Typically $1.6 \mathrm{~kg}$ of aluminum was required to treat $1 \mathrm{~kg}$ of $\mathrm{NaNO}_{3}(1.9 \times$ stoichiometric), in the batch tests, with most of the excess aluminum required to rezct with the last $10 \%$ of the nitrate. ${ }^{1}$ As the nitrate concentration decreases, more aluminum reacts with water to form hydrogen gas. Laboratory-scale tests have demonstrated that a smaller excess of aluminum (1.1 $\times$ stoichiometric) is required to destroy essentially all of the nitrate using a continuous-flow reactor, ${ }^{2}$ as shown in the following reaction:

$$
3 \mathrm{NaNO}_{3}+8.8 \mathrm{Al}+14.4 \mathrm{H}_{2} \mathrm{O} \rightarrow 3 \mathrm{NH}_{3} \uparrow+5.8 \mathrm{Al}(\mathrm{OH})_{3}+3 \mathrm{NaAlO}_{2}+1.2 \mathrm{H}_{2} \uparrow
$$

Radioactively contaminated aluminum scrap from DOE facilities could be beneficially used in the process.

This process occurs in alkaline solutions ( $\mathrm{pH}>11.5$ ) at slightly elevated temperatures $\left(>50^{\circ} \mathrm{C}\right)$. The reaction is highly exothermic $\left(-381 \mathrm{kcal} / \mathrm{mol}\right.$ of $\left.\mathrm{NaNO}_{3}\right)$; therefore, the solution will need to be cooled after the reaction is initiated. For high-nitrate-concentration waste solutions, water would need to be added to keep the slurry dilute enough to mix. The reaction products form a granular, sand-like material that can be dried, pressed, and sintered to form an insoluble alumina-silica ceramic as the final waste form. Silica is added to the reactor to immobilize the sodium in the ceramic waste form. The volume of the final solid waste form will be about $70 \%$ less than the starting solution for a $4 \mathrm{M} \mathrm{NaNO}_{3}$ solution. The aluminum hydroxide will co-precipitate and/or adsorb many inorganic contaminants from the waste solution, such as heavy metals and ${ }^{90} \mathrm{Sr}$, which will be incorporated into the insoluble final waste form.

If oxygen is present, the off-gas will be flammable because of the ammonia and hydrogen produced; thus, an inert gas blanket will be required for the reactor. The off-gas will need to be treated to remove ammonia, probably by catalytic oxidation to convert the ammonia to nitrogen gas and water.

The proposed flowsheet for the process is shown in Fig. 1. A preliminary cost estimate was performed in 1992 by D. E. Brashears of Martin Marietta Energy Systems' Central Engineering. For a plant to process $1200 \mathrm{~kg} \mathrm{NO}_{3}-\mathrm{h}$ over 20 years, the estimated capital cost is $\$ 20 \mathrm{M}$, with an operating cost of $\$ 2$ to $\$ 3 / \mathrm{kg} \mathrm{NO}_{3}^{-}$destroyed. ${ }^{1}$ 


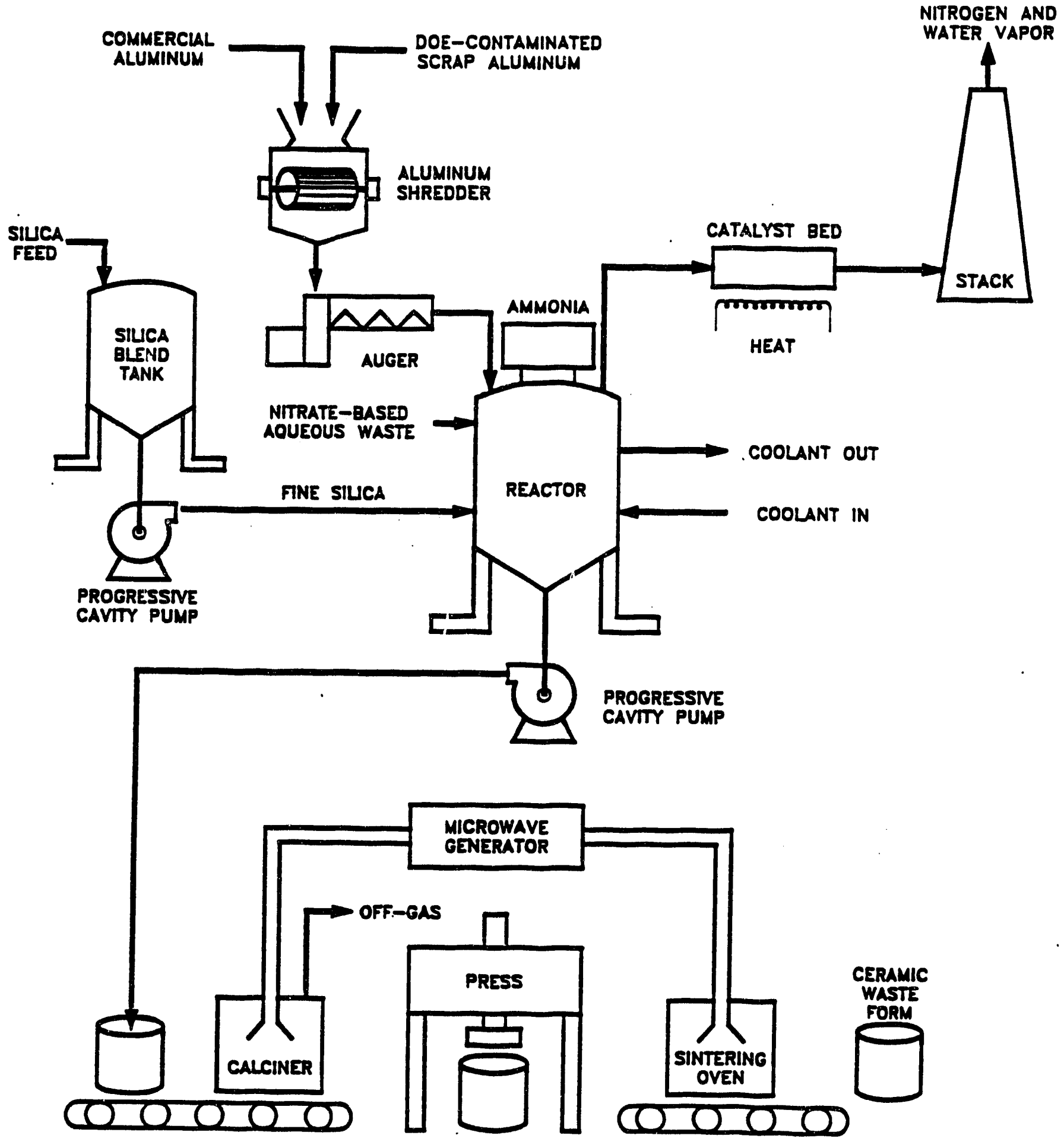

Fig. 1. Flow diagram for nitrate to ammonia and ceramic process. 


\subsection{Technology Status}

This technology has been tested in laboratory-scale experiments using surrogates for the Hanford and ORNL wastes.

\subsubsection{Advantages}

This process occurs at a relatively low temperature $\left(50^{\circ} \mathrm{C}\right)$ and atmospheric pressure. Essentially all the nitrate can be destroyed. The process will precipitate ${ }^{90} \mathrm{Sr}$ and heavy metals that may be present in the waste. An insoluble solid waste form is produced which will be smaller in volume than the starting solution (about $70 \%$ less for a $4 \mathrm{M} \mathrm{NO}_{3}$ - solution); this process compares to a volume increase of about $40 \%$ for grouting the wastewater. The alkaline waste solutions that are stored at Hanford, ORNL, and SRP will not require any pretreatment prior to nitrate destruction.

\subsubsection{Disadvantages}

Because the process converts nitrate to ammonia rather than nitrogen gas, further off-gas treatment will be required. The ammonia and hydrogen gas produced by the reaction are potentially explosive; consequently, an inert gas must be maintained in the system. Because the process is highly exothermic, safety controls will be required to prevent a runaway reaction. The solid waste form generated by the process has not yet been qualified as acceptable for final disposal, although it should easily qualify.

\subsubsection{Evaluation}

The main advantage of this process is that a solid, insoluble waste form is produced, although the waste form has not yet been qualified for final disposal. The waste form will trap many of the radionuclides present in the waste solution and will result in a significant volume reduction compared tc grouting the liquid wastes. Because the process has been tested only in laboratoryscale equipment using surrogate solutions, significant development work will be required before the process can be completely evaluated. Because of the ammonia and hydrogen produced in the off-gas and the large amount of energy produced during the reaction, many safety concerns will need to be addressed. The process could be used directly on the alkaline waste solutions stored at Hanford, ORNL, and SRP, but acidic waste streams would require $\mathrm{pH}$ adjustment before treatment.

\section{EILECTROCHEMICAL DESTRUCTION}

\section{Process Description}

Electrochemical destruction of nitrate and nitrite containing mixed wastes shows promise in reducing the volume of residual wastes in effluent waste streams as well as being competitive with other wet-processing approaches on, at the least, the basis of power consumption. This method of destroying nitrates is under development by Bradtec, Inc. (Bristol, United Kingdom), AEA Industrial Technology (Oxfordshire, United Kingdom), and researchers at SRP. The process has 
been tested on simulants for radioactive waste streams expected at RFP and SRP. ${ }^{4.5}$ In all cases, electrochemical destruction of nitrates has been proposed using a cell such as shown in Fig. 2.

The approach being investigated for the RFP involves a process that is being demonstrated for a variety of applications. ${ }^{36}$ Bradtec's electrochemical ion-exchange (EIX) process consists of the separation of the nitrate from the waste stream by an anion-exchange resin followed by migration of the nitrate anions to an anode. The nitrate can be recovered as nitric acid, or it can be destroyed in an electrochemical cell to produce nitrogen and other products, thus reducing the volume of the waste stream.

Electrochemical methods of reducing the amount of nitrate and nitrite in mixed waste at SRP have been investigated for several years using single- and multiple-cell electrolysis compartments. Investigations on SRP wastes indicate that electrolysis is a viable means of destroying nitrates and nitrites. The presence of chromium in the waste solution can reduce the electrical efficiency of the process because of cyclic oxidation and reduction. The electrical efficiency can be reduced from $>90 \%$ to $<40 \%$ by $16 \mathrm{mg} / \mathrm{L}$ chromium.

The electrochemical destruction of nitrate is brought about by reduction to nitrogen at a cathode in a destruction cell such as the one shown in Fig. 2. This is achieved by making the nitrate-anolyte mixture follow a route through a series of bipolar electrodes in the anode compartment. Monopolar electrochemical destruction has been considered by several investigators, but the bipolar cell design has been found to be more effective. ${ }^{4}$ The cells also have the potential of oxidizing organics in the waste at the anode. Concentration of nitrates from dilute aqueous streams, such as groundwater, has also been investigated by incorporating EIX along with the destruction cell., 3

The conversion of nitrate to nitrogen (the preferred product) or ammonia is achieved through a series of sequential reduction steps. Because some of the intermediate species are unstable and short-lived, only the important reactions in the destruction process are given below:

$$
\begin{aligned}
& \mathrm{NO}_{3}^{-}+\mathrm{H}_{2} \mathrm{O}+2 \mathrm{e}^{-} \Rightarrow \mathrm{NO}_{2}^{-}+2 \mathrm{OH}^{-} \\
& \mathrm{NO}_{3}^{-}+3 \mathrm{H}_{2} \mathrm{O}+5 \mathrm{e}^{-} \Rightarrow>0.5 \mathrm{~N}_{2}+6 \mathrm{OH}^{-} \\
& \mathrm{NO}_{3}^{-}+6 \mathrm{H}_{2} \mathrm{O}+8 \mathrm{e}^{-} \Rightarrow \mathrm{NH}_{3}+9 \mathrm{OH}^{-}
\end{aligned}
$$

However, measurable quantities of $\mathrm{NH}_{4}^{+}, \mathrm{N}_{2} \mathrm{O}, \mathrm{H}_{2}$, and $\mathrm{O}_{2}$ can be expected as additional products in destroying nitrates and nitrites.3.5 For aqueous wastes with dilute concentrations of nitrates, destruction can be facilitated by concentration of the nitrates. One approach to concentration involves the EIX process that combines ion exchange and electrodialysis with destruction. ${ }^{3}$

\subsection{Technology Status}

Destruction of nitrates by electrolysis has been investigated for a number of years for its applicability to radioactive mixed wastes. ${ }^{3-6}$ The EIX process has been examined specifically for wastes from RFP; a pilot-scale plant has been proposed. ${ }^{3}$ Research using SRP wastes has determined that the efficiency of the reduction of nitrates and nitrites depends on the current density, presence of chromate ion, temperature, and electrode spacing. 


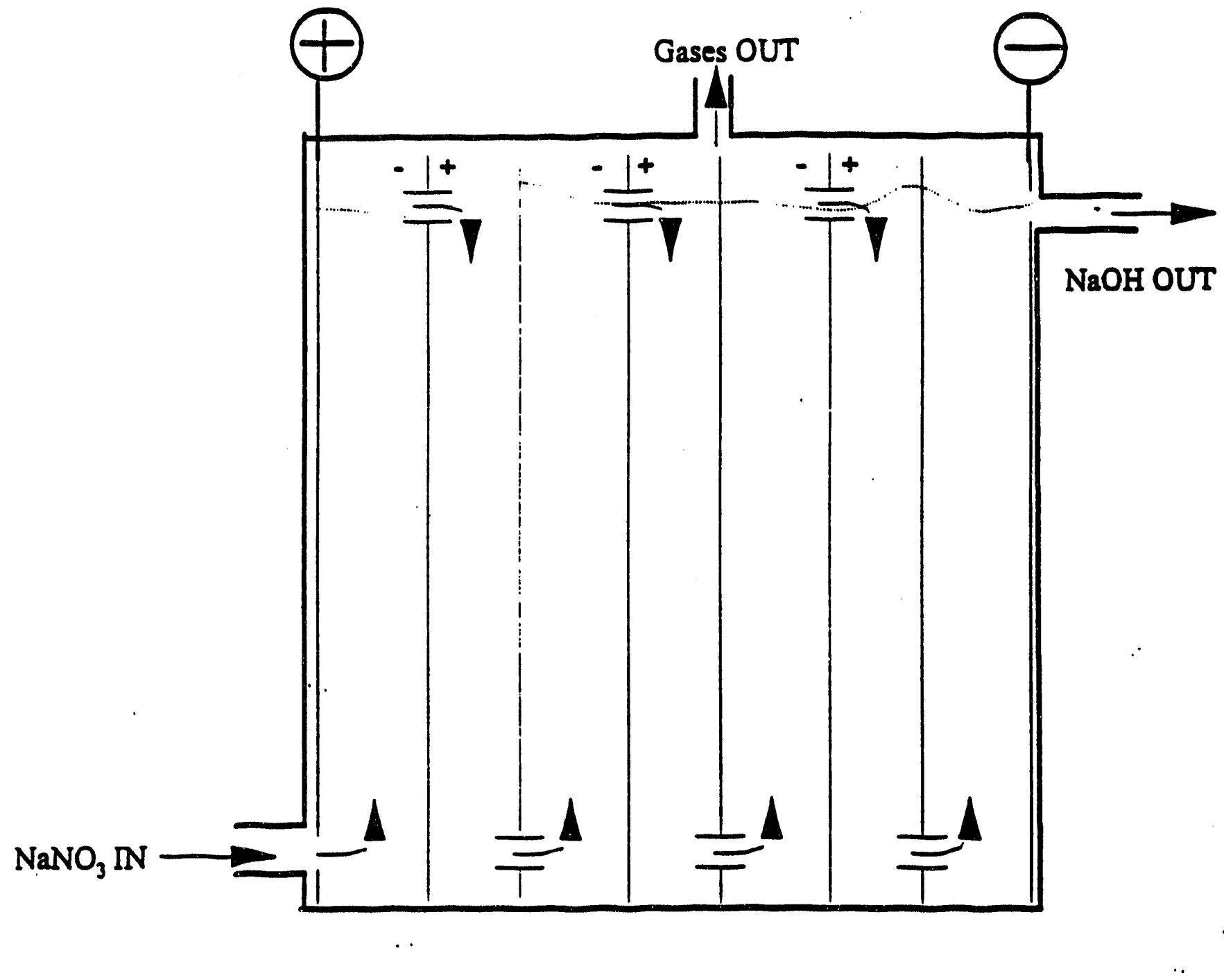

Figure 2. Destruction cell used to reduce nitrates. Source: Atkins, K.J., D. Bradbury, G.R. Edler, and S.M. Scrivens, Electrochemical Ion Exchange Treatment of Plutonium-Bearing Nitrate Waste, BRADTEC Ltd., Bristol Polytechnic, Coldharbour Lane, Bristol BS16 1QY, United Kingdom, November 1992. 


\section{Advantages}

There are a number of advantages in using the electrochemical process to destroy nitrates. Significantly, no secondary wastes are formed with the simple use of a destruction cell because the process does not require addition of significant quantities of other chemicals. The process could be used on acidic or alkaline waste streams without pretreatment. For acidic solutions, the waste will be neutralized while the nitrate is being destroyed. The potential exists for simultaneously destroying organics at the destruct cell anode. For dilute nitrate wastes, where an ion-exchange resin might be used in the EIX process, the resin is used continuously and requires no additional regeneration.

\section{Disadvantages}

Electrolysis affects ions other than the nitrates that are intended to be destroyed. In some cases, the products plate-out on electrodes; however, this problem can be solved partially by proper electrode selection, reversing electrode currents where possible, or removing problem ions before destruction., 4 Use of porous membranes has also resulted in some problems with fouling. ${ }^{4}$ Chromium concentrations above $1 \mathrm{mg} / \mathrm{L}$ significantly reduce the electrical efficiency of the process.

Release of the off-gases will require further evaluation. The $\mathrm{NH}_{3}$ and $\mathrm{N}_{2} \mathrm{O}$ may have to be treated, depending on the amounts produced and on local and national environmental regulations. The possible formation of $\mathrm{NO}_{2}$ as a result of $\mathrm{NO}$ (gas) combining with $\mathrm{O}_{2}$ (gas) in separation of nitrates from dilute nitric acid may warrant evaluation. ${ }^{3}$ Hydrogen generation at the cathode presents a safety concern because a potential exists for the formation of an explosive mixture of gases.

The electromigration of ions in aqueous solutions is accompanied by electroosmosis, a process in which water diffuses through the membrane. This can, if not controlled, lead to volume imbalances over long treatment periods. In addition, the electrolysis process consumes water and requires significant quantities of makeup water. The treated solutions would have to be solidified for final disposal, which would increase the volume by about $40 \%$.

\subsubsection{Evaluation}

The development of the electrochemical destruction of mixed wastes appears to be maturing commensurate with the needs for waste disposal. At least three companies are actively pursuing this form of waste minimization, and work is continuing. Power consumption for this process appears reasonable by comparison with other waste processes, and the minimal need for addition of other chemicals shows considerable promise in reducing the final waste volumes. Bradtec indicates that power requirements are relatively low at $0.96 \mathrm{kWh} / \mathrm{g} \mathrm{mol} \mathrm{of} \mathrm{NO}_{3}{ }^{-}$ destroyed or a total of $1.6 \mathrm{kWh} / \mathrm{g}$ mol for both separation by EIX and destruction. ${ }^{3}$ Such power consumption at $\$ 0.03 / \mathrm{kWh}$ would result in power costs of $\$ 0.46 / \mathrm{kg} \mathrm{NO}_{3}{ }^{-}$to destroy nitrates.

The investigation of electrochemical destruction for specific radioactive mixed wastes supports the use of this process. As an example, treating $8 \mathrm{~L} / \mathrm{min}$ of Hanford supernate is expected to require about $2.1 \mathrm{MW}$ of power if concentration with EIX is used. As explained previously, the off-gas will contain $\mathrm{N}_{2}, \mathrm{NH}_{3}$, and $\mathrm{N}_{2} \mathrm{O}$. Heat generated by the electrodes during this process has been addressed by several investigators; the heat can be removed by the circulating fluids. 
Extensive development work would be required before a treatment facility could be designed and built. The treated wastewater would need to be solidified before final disposal. Costs for building and operating a treatment facility have not been estimated.

\subsection{BIOLOGICAL DENITRUFICATION}

\subsubsection{Process Description}

Biological denitrification has been used at the Oak Ridge Y-12 Plant since 1976 to treat highly concentrated nitrate wastes. More dilute waste streams are being treated in fluidized-bed bioreactors at the Portsmouth Gaseous Diffusion Plant and the Fernald Feed Materials Plant. The nitrate is converted to nitrogen gas and carbon dioxide. A readily biodegradable organic carbon source must be supplied to the bacteria, and moderate temperatures ( 15 to $50^{\circ} \mathrm{C}$ ) and $\mathrm{pH}$ (7.5 to 8.5) must be maintained in the bioreactor for optimal denitrification rates. The feed stream to the Y-12 bioreactors contains about $5 \mathrm{M}$ total nitrate (mostly aluminum nitrate) and about 1.5 $M$ nitric acid. Calcium acetate is supplied as the organic carbon source. The bioreactors cian treat about $2 \mathrm{~g} \mathrm{NO}_{3}-\Lambda$ of reactor volume/d. The denitrification reaction produces enough alkalinity to neutralize the feed and maintain a pH of about 7.5 in the bioreactor as long as the feed solution contains less than $1.5 \mathrm{M}$ free nitric acid. The bioreactor produces a sludge that contains calcium carbonate, aluminum hydroxide and biomass.,8

Feeding highly concentrated nitrate wastes to a bioreactor is feasible only if the cations in the waste will precipitate in the bioreactor. For soluble cations, such as sodium, the concentration of the waste stream fed to the bioreactor is limited by the tolerance of the bacteria for the cation. In the case of sodium, high denitrification rates have been observed at sodium concentrations up to $1.2 \mathrm{M}$. It may be possible to isolate or develop bacterial strains that could tolerate even higher sodium concentrations. Acute radiation experiments have demonstrated that $0.3 \mathrm{rad} / \mathrm{s}$ should not adversely affect the denitrification bacteria. ${ }^{9}$

\subsubsection{Technology Status}

Biological denitrification has been used for over 15 years to treat high nitrate-concentration mixed wastes at the Oak Ridge Y-12. Plant. These wastes contain low concentrations of uranium, but they do not contain fission products like most of the currently stored mixed wastes. The process has not been tested on the high sodium-nitrate concentration mixed wastes that are stored at DOE facilities.

\subsubsection{Advantages}

The main advantage of biological denitrification is that the nitrate is converted to nitrogen gas at ambient temperature and pressure. The required equipment is simple, readily available, and easily operated.

\subsubsection{Disadvantages}

Disadvantages of the process include both the narrow $\mathrm{pH}$ and salt concentration ranges that the bacteria can tolerate and aiso a slow denitrification rate, which dictates large bioreactors. Wastes that contain high sodium concentrations, which include most of the stored wastes, will 
require dilution prior to treatment. The sludge produced during the process would require further treatment to stabilize or destroy the biomass to prevent off-gassing during storage.

\subsubsection{Evaluation}

Unless an order-of-magnitude improvement is found in sodium tolerance for denitrification bacteria, the high-pH mixed wastes stored at Hanford, ORNL, and SRP would need to be diluted significantly before biodenitrification could be used to destroy the nitrates. Also, the waste would have to be neutralized; this would requre large amounts of acid and might solubilize additional radionuclides and heavy metals. Significant effort has been expended in the past to reduce the volume of these stored wastes as much as possible; consequently, diluting the wastes for nitrate treatment would be very undesirable. The treated waste would require further treatment, such as biomass destruction and grouting, before final disposal to solidify the waste and prevent offgassing during storage.

Acid waste streams, such as those at RFP and INEL, appear to be better candidates for this technology, although these streams are currently being solidified. The wastes may need to be partially neutralized with lime prior to treatment. Any dilute mixed-waste streams that may be produced in the future would be good candidates for biodenitrification. The cost for operating the Y-12 Plant bioreactors is about $\$ 4 / \mathrm{kg} \mathrm{NO}_{3}{ }^{-}$, but costs for a remote-handled facility would be much higher.

\subsection{CHEMICAL REDUCTION}

\subsubsection{Process Description}

A wide range of reducing agents, such as formic acid, formaldehyde, sugar, and ammonia, can be used to convert nitrate to a mixture of nitrogen gas and $\mathrm{NO}_{\mathbf{z}}$ 's. Examples of the reactions that can occur with formic acid are shown below. ${ }^{10}$

$$
\begin{aligned}
& 2 \mathrm{HNO}_{3}+\mathrm{HCOOH} \rightarrow 2 \mathrm{NO}_{2}+\mathrm{CO}_{2}+2 \mathrm{H}_{2} \mathrm{O} ; \\
& 2 \mathrm{HNO}_{3}+3 \mathrm{HCOOH} \rightarrow 2 \mathrm{NO}+3 \mathrm{CO}_{2}+4 \mathrm{H}_{2} \mathrm{O} ; \\
& 2 \mathrm{HNO}_{3}+4 \mathrm{HCOOH} \rightarrow \mathrm{N}_{2} \mathrm{O}+4 \mathrm{CO}_{2}+5 \mathrm{H}_{2} \mathrm{O} ; \\
& 2 \mathrm{HNO}_{3}+5 \mathrm{HCOOH} \rightarrow \mathrm{N}_{2}+5 \mathrm{CO}_{2}+6 \mathrm{H}_{2} \mathrm{O} .
\end{aligned}
$$

The denitration of high-level waste (HLW) using formaldehyde has been performed for many years at the Marcoule and La Hague plants in France and at the Tokai-Mura plant in Japan. Formaldehyde is metered into a boiling solution of $\mathrm{HLW}$ at a controlled rate. Because the process is used mainly to adjust the acidity and nitrate concentration of the HLW prior to extraction processes, destroying all the nitrate is not a goal of these facilities. There is normally an induction period after the formaldehyde is added to the HLW before the reaction initiates. If excessive amounts of formaldehyde build up in the solution before the reaction starts, rapid reaction rates could produce high pressures in the reaction vessel. Several incidents of this type have occurred in the full-scale facilities with minor consequences. ${ }^{11}$ There is also the possibility of 
an unstable oscillatory reaction, caused by periodic build-up of reactants followed by very rapid reaction, occurring if noble metals, such as palladium, are present in the waste solution. ${ }^{12}$

The off-gas will contain high concentrations of $\mathrm{NO}_{\dot{x}}$ thus, treatment will normally be required. The gas could be scrubbed, but this will produce large volumes of radioactively contaminated nitric acid or nitrate salts that will require further treatment for disposal. The preferred treatment for the off-gas would be catalytic reduction with ammonia, which will produce nitrogen gas. ${ }^{13}$

\subsection{Technology Status}

Nitrate reduction with formaldehyde has been used for many years to reduce the acidity of HLW at full-scale facilities in France and Japan. The process is potentially unstable, but it has been successfully used for many years with only minor incidents.

\subsubsection{Advantages}

The process has been used for many years in full-scale facilities on acidic HLW.

\subsubsection{Disadvantages}

Because the nitrate is converted to nitrogen oxides rather than nitrogen gas, further off-gas treatment would be required. Because the alkaline wastes at Hanford, ORNL, and SRP would need to be acidified before treatment, huge amounts of acid would be required. The process is potentially unstable; therefore, safety controls will be required to prevent a runaway reaction. The process is not normally capable of destroying all of the nitrate; consequently, substantial concentrations of nitrate would still be present in the waste after treatment. Because the treated waste would need to be solidified before final disposal, its volume would be increased.

\subsubsection{Evaluation}

The chemical reduction process has been used for many years in France and Japan without serious incident, in spite of the potential for unstable or runaway reactions. The process has not been tested on the alkaline mixed wastes stored at DOE facilities. Unless methods are developed to use the process under alkaline conditions, large amounts of acid would be required for $\mathrm{pH}$ adjustment before treatment. Also, extensive development work would be required before a facility could be designed and built to process DOE wastes. The treated solution would require solidification before final disposal. Cost for building and operating a chemical reduction facility should be similar to those for the NAC process facility.

\subsection{HYDROTHERMAL PROCESS}

\subsubsection{Process Description}

The hydrothermal process is a variation of the chemical reduction process, with the chemical reduction occurring at higher temperatures and pressures. The same range of reducing agents could be used, but other, more refractory, compounds, such as ferrocyanides, which may already be present in the waste, will also react with the nitrate under these conditions. 
Laboratory-scale tests have shown that formic acid can be used to destroy essentially all of the nitrate in a $3 \mathrm{wt} \% \mathrm{NO}_{3}{ }^{-}$solution within $2 \mathrm{~h}$ under acidic $(\mathrm{pH}=4)$ or basic $(\mathrm{pH}=13)$ conditions in a pressurized vessel $\left(\mathrm{T}=350^{\circ} \mathrm{C}\right.$ and pressure $\left.=19 \mathrm{MPa}\right)$. In the acidic solution, essentially all of the nitrate was converted to nitrogen gas, but in the basic solution, only about $50 \%$ was converted to nitrogen gas, and the remainder was unaccounted for. ${ }^{14}$ Other reductants, such as ammonia, urea, methane, and hydrogen, were tested under similar conditions, but they were found to be less effective, particularly at high $\mathrm{pH}$.

Laboratory-scale tests have demonstrated that various organics and ammonia will react with nitrate under supercritical or near supercritical conditions ( 450 to $525^{\circ} \mathrm{C}$ and $30 \mathrm{MPa}$ ). A mixture of nitrogen gas and nitrous oxide is produced from the witrate. Potassium ferrocyanide, which is present in the Hanford waste, will react with nitrate at $500^{\circ} \mathrm{C}$ and $30 \mathrm{MPa}$. Most salts are only slightly soluble in supercritical water; for example, sodium nitrate has a solubility of $293 \mathrm{ppm}$ at $525^{\circ} \mathrm{C}$ and $24.8 \mathrm{MPa}$. Low solubility may make it difficult to get high sodium-nitrate-concentration solutions into the reactor, but also opens the possibility for removing the reaction products (i.e., sodiuin hydroxide) and other radionuclides and heavy metals as a solid waste. ${ }^{15}$

\subsection{Technology Status}

This technology has been tested in laboratory-scale experiments using a surrogate for the Hanford tank waste and other more dilute nitrate solutions.

\subsection{Advantages}

This technology is similar to the chemical reduction process. The main advantages are that organics present in the waste could be used to destroy nitrate, thus, converting the organics to carbon dioxide and minerals. Also, both acidic and alkaline solutions could be treated using this process. Under some conditions, almost all of the nitrate can be converted to nitrogen gas. It may be possible to separate most of the salts and some radionuclides and heavy metals as a solid waste. If the majority of the salts are removed, the dilute water solution remaining could be greatly reduced in volume by evaporation before solidification for final disposal.

\subsubsection{Disadvantages}

Because nitrates and other salts have limited solubility in supercritical water, plugging of the lines to and from the reactor is a concern. Because the high temperatures and pressures used in the process will increase corrosion rates, exotic materials will probably be required for the reactor. Further processing, such as grouting, will be required to solidify the waste prior to final disposal. Off-gas treatment may be required for $\mathrm{NO}_{2}$ 's.

\subsubsection{Evaluation}

This process has the potential for destroying nitrates in both acidic and alkaline wastes without any required pretreatment. Under some conditions the nitrate is converted almost completely to nitrogen gas. A major advantage of this method is that organics present in the waste will be destroyed at the same time as the nitrate. The treated solution will require solidification before final disposal, although the volume of solid waste may be greatly reduced if the salts are separated from the supercritical water in the reactor. Extensive development work would be 
required before a facility could be designed and built. The costs for building and operating a iacility have not been estimated.

\subsection{CALCINATION}

\subsubsection{Process Description}

Aqueous radioactive wastes at $\mathrm{NEEL}$ are stabilized and solidified in a fluidized-bed calcining facility called the New Waste Calcining Facility (NWCF). The 1.5-m diam calciner, which is heated to $500^{\circ} \mathrm{C}$ by in-bed combustion, will process about $200 \mathrm{gal} / \mathrm{h}$ of waste, producing a dry granular solid for storage. The NWCF treats a variety of wastewaters, including wastes high in aluminum, zirconium, fluoride, and ammonia as well as nitrate. The concentration of sodium nitrate in the feed is strictly controlled to prevent caking of the calcine. Sodium nitrate melts at $308^{\circ} \mathrm{C}$, and mixtures of sodium nitrate with potassium, calcium, or magnesium nitrate melt at even lower temperatures. Sodium nitrate decomposes to produce $\mathrm{Na}_{2} \mathrm{O}$ and $\mathrm{NO}_{2}$ in the range of 600 to $900^{\circ} \mathrm{C}$, which is above the temperature limit for the NWCF. ${ }^{16}$ Small amounts of sodium-bearing wastes are calcined by mixing them with other waste solutions, but inventories of sodium wastes are accumulating because of the limited amount of sodium allowed in the NWCF. The cost for calcining waste in the NWCF is about $\$ 37 / \mathrm{L}\left(\$ 130 / \mathrm{kg} \mathrm{NO}_{3}{ }^{-}\right)$. [B. H. O'Brien, Idaho National Engineering Laboratory, Idaho Falls, Idaho, personal communication to P. A. Taylor, Oak Ridge National Laboratory, Oak Ridge, Tennessee, March 24, 1993.]

Pilot-scale tests have demonstrated that the ratio of sodium wastes entering the NWCF can be increased by adding sucrose to the waste solution. The sucrose reacts with the nitrate to produce $\mathrm{NO}_{x}$ as described in the chemical reduction process section of this report. Potential problems identified in the pilot-scale tests include possible plugging of off-gas filters by unburned sucrose, increasing the amount of fines produced, and caking of the solids during storage. Further development tests were recommended. ${ }^{17}$

At higher temperatures $\left(>2000^{\circ} \mathrm{C}\right)$ nitrates can be converted directly to nitrogen gas. Pilotscale tests using a plasma torch have demonstrated that a mixture of sodium and potassium nitrate can be converted to solid carbonates and nitrogen gas. The equipment consisted of a plasma torch, which generates extremely high temperatures by passing nitrogen or argon gas through a magnetically rotated electric arc producing an incandescent stream of ionized gas, and a graphitelined, coke-filled furnace that served as a reaction chamber. ${ }^{18}$ The coke reacted with the sodium and potassium oxides produced by the torch to yield carbonates.

An aqueous waste, consisting of magnesium, aluminum, and calcium nitrates and nitric acid, which simulated a raffinate waste produced at the Feed Materials Production Center at Fernald, Ohio, was also calcined using a Westinghouse Marc 3 plasma torch. The torch was operated at a power level of 98 to $173 \mathrm{~kW}$ with air as the carrier gas, which yielded a reactor temperature of about $1200^{\circ} \mathrm{C}$. The raffinate simulant was fed to the torch at a flow rate of $0.25 \mathrm{~L} / \mathrm{min}$. The reaction product was primarily metal oxides containing $<1 \%$ nitrates. With air as the carrier gas, the torch generated about $1800 \mathrm{ppm} \mathrm{NO}$ in the off-gas prior to feed addition, which increased to about $\mathbf{2 1 0 0}$ ppm NO after feed addition. Most of the nitrates in the feed were converted to nitrogen gas. ${ }^{19}$ 


\subsubsection{Technology Status}

Calcination has been used at INEL for many years to solidify low-sodium wastes. Pilot-scale tests have demonstrated that higher concentrations of sodium can be processed if sugar is added to the waste solution. High-temperature processing, such as with a plasma torch, can decompose nitrates to nitrogen gas and $\mathrm{NO}_{\mathbf{x}}$ and would destroy any organics in the waste. Pilot-scale tests using waste surrogates have demonstrated that a plasma torch can convert a solution of metal nitrates to solid metal oxides.

\subsection{Advantages}

Calcination is a well-established process for treating low-sodium concentration wastes. A full-scale calciner has been operating at INEL for almost 30 years. Wastes with moderate concentrations of sodium can be processed by appropriately blending them with other waste streams. Pilot-scale tests have demonstrated that adding sugar to the waste solution can increase the allowable concentration of sodium nitrate by chemically reducing the nitrate during calcining.

Pilot-scale tests have demonstrated also that a plasma torch can decompose a mixture of sodium and potassium nitrate and a solution of metal nitrates. The nitrates are primarily converted to nitrogen gas.

\subsubsection{Disadvantages}

The calcination process used at INEL will not work for the alkaline wastes stored at Hanford, ORNL, and SRP, which are primarily sodium nitrate. The sodium nitrate melts, but does not decompose, at the calciner's operating temperature of $500^{\circ} \mathrm{C}$. The off-gas from the calciner must be treated to remove $\mathrm{NO}_{x}$ which is the primary decomposition product of metal nitrates at $500^{\circ} \mathrm{C}$.

High-temperature processes, such as using a plasma torch, would require extensive development work before a full-scale facility could be designed and built. Sodium nitrate would be converted to sodium oxide, which is very reactive and bygroscopic. Using a coke-filled furnace would convert the oxides to carbonates, which are stable, but would make the solids difficult to recover. The amount of radionuclides that would be volatilized during the process has not been determined.

\subsubsection{Evaluation}

Calcination is a well-established process for solidifying low-sodium concentration wastes. Using the technology to treat the high sodium-nitrate-concentration wastes stored at most DOE facilities is not feasible at the present. The cost for calcining waste in the NWCF is about $\$ 37 / \mathrm{L}$ $\left(\$ 130 / \mathrm{kg} \mathrm{NO}_{3}^{-}\right)$. (B. H. O'Brien, Idaho National Engineering Laboratory, Idaho Falls, ID, personal communication to P. A. Taylor, Oak Ridge National Laboratory, Oak Ridge, Tennessee, March 24, 1993).

Higher temperature processes, such as a plasma torch, can convert sodium nitrate to nitrogen gas and sodium oxide, which is very reactive and would require stabilization. Enough energy would need to be supplied to evaporate all of the water from the waste solutions. The fate of the radionuclides in the waste has not been determined. 


\section{SUMMARY}

A wide variety of high nitrate-concentration aqueous mixed (radioactive and RCRA hazardous) wastes are stored at various DOE facilities. Examples of the composition of the major nitrate-containing wastes were listed. These wastes will ultimately be solidified for final disposal, although the final methods and criteria for solidification and disposal are still being developed. The nitrates in the waste will generally increase the volume or reduce the integrity of the final waste form; therefore, nitrate desiruction before solidification will generally be beneficial. This report has described the various technologies that could be used to destroy the nitrates in the stored wastes. All the technologies identified, except the calcining of low sodium-concentration wastes, will require further development work before a facility can be designed and built for treating the stored wastes. Several of the technologies have particularly attractive features: the NAC process produces an insoluble waste form with a significant volume reduction, electrochemical reduction destroys nitrates without any chemical addition, and the hydrothermal process can simultaneously treat nitrates and organics in both acidic and alkaline wastes.

Three processes have been used to treat high nitrate-concentration wastes at full-scale facilities. Calcining is a vell-established process at INEL for solidifying low sodium-concentration waste streams, but it is not applicable to the alkaline wastes stored at most other DOE facilities. Biological denitrification is also being used at the Y-12 Plant in Oak Ridge, Tennessee, to treat wastes containing high concentrations of aluminum nitrate and nitric acid. Wastes with high sodium concentrations, which include most of the stored wastes, would require neutralization and signizicant dilution before biodenitrification was possible. Chemical reduction has been used in Europe and Japan to treat acidic high-level wastes for many years. The process will not normally destroy all the nitrate in the waste and will not work in alkaline solutions. None of these rechnologies appear promising for treating the high-nitrate-concentration, alkaline, mixed wastes stored at most DOE facilities.

Three technologies appear to merit further development: the NA.C process, electrochemical reduction, and hydrothermal treatment. Each process has unique advantages and disadvantages, but each will require significant experimental work to determine its respective applicability for full-scale treatment of specific waste streams. Cost estimates have been made for some of these teshnologies, the NAC process in particular, based on limited design data. It should be noted that the operating costs for the calcination process at INEL, which is the only process currently being used on highly radioactive wastes at a DOE facility, are considerably higher than the estimates Shat have been made for the other processes, even though the calcination process is less complicated.

It is recommended that development work continue on the NAC, electrochemical destruction, and lyydrothermal processes. More information is needed on the capabilities and potential probiems of these processes before a reasonable decision can be made to determine which would be the best method for treating a particular waste stream. Also, the overall system requirements for radioactive waste disposal, and in particular the waste acceptance criteria for the final waste form, will need to be finalized before a determination can be made on whether nitrate destruction is required, as well as providing criteria for comparing the various nitrate destruction processes. The development work should include pilot-scale tests to further define the operating limits, through-puts, required process/safety controls and economics of the processes, and smallscale tests on actual waste solutions to identify any potential problems caused by minor waste constituents. 


\section{REFERENCES}

1. A. J. Maitus et al., A Low-temperature Prucess for the Denitration of Hanford Single-Shell Tank, Nitrate-Based Waste Utilizing the Nitrate to Ammonia and Ceramic (NAC) Process, ORNL/TM-12245, Martin Marietta Energy Systems, Inc., Oak Ridge National Laboratory, Oak Ridge, Tenn., August 1993.

2. A. J. Mattus, D. D. Lee, and T. A. Dillow, A Low-temperature Process for the Denitration of Hanford Single-shell Tank, Nitrate-based Waste Utilizing the Nitrate to Ammonia and Ceramic (NAC) Process: Experiments in the Continuous Mode, Letter Report, Martin Marietta Energy Systems, Inc., Oak Ridge National Laboratc; , Oak Ridge, Tenn., March 15, 1993.

3. K.J. Atkins, D. Bradbury, G.R. Edler, and S.M. Scrivens, Electrochemical Ion Exchange Treatment of Plutonium-Bearing Nitrate Waste, BRADTEC Ltd., Bristol Polytechnic, Coldharbour Lane, Bristol BS16 1QY, Bristol, United Kingdom, November 1992.

4. D. T. Hobbs, and M. A. Ebra, "Electrochemical Processing of Alkaline Nitrate and Nitrite Solutions." In AIChE Symposium Ser. 83(254), pp. 149-155 (1987).

5. Electrosynthesis Company, Inc., Electrochemical Processing of Nitrate Waste Solutions, WSRC-TR-90-491, Westinghouse Savannah River Company, Aiken, South Carolina, May 31, 1992.

6. D. Bradbury, G. R. Elder, and G. L. Kalinauskas, Removal and Destruction of Nitrates from Wastewater and Groundwater, Bradtech-US, Inc., Atlanta, Georgia, and Bradtech Ltd., Bristol, United Kingdom, 1992.

7. F. E. Clark, C. W. Francis and J. W. Strohecker, Denitrification of Acid Wastes From Uranium Purification Processes, Y-1990, Union Carbide-Nuclear Division, Oak Ridge Y-12 Plant, Oak Ridge, Tenn., November 1975.

8. F. E. Clark, J. M. Napier, and R. B. Bustamante, "Biological Treatment of Concentrated Nitrate Wastes," Y/DA-6967, Union Carbide-Nuclear Division, Oak Ridge Y-12 Plant, Oak Ridge, Tenn., April 1977.

9. C. W. Francis and C. W. Hancher, "Biological Denitrification of High-nitrate Wastes Generated in the Nuclear Industry", pp. 234-50 in Biological Fluidised Bed Treatment of Water and Wastewater, eds. P. F. Cooper and B. Atkinson, Ellis Horwood Limited, Chichester, England, 1981.

10. L. Cecille and M. Kelm, "Chemica! Reactions Involved in the Denitration Process With HCOOH and HCHO," pp. 17-37 in Denitration of Radioactive Liquid Waste, eds. L Cecille and S. Halaszovich, Graham and Trotman, Norwell, Massachusetts, 1986. 
11. C. Breschet, D. Pageron, F. Drain and V. Decobert, "Industrial Application of Denitration of HLW By Means of HCHO", pp. 168-77 in Denitration of Radioactive Liquid Waste, eds. L. Cecille and S. Halaszovich, Graham and Trotman, Norwell, Massachusetts, 1986.

12. T. Schulenberg, "Safety Aspects About Denitration", pp. 57-63 in Denitration of Radioactive Liquid Waste, eds. L. Cecille and S. Halaszovich, Graham and Trotman, Norwell, Massachusetts, 1986.

13. A. Donato, "Abatement of the $\mathrm{NO}_{\mathbf{z}}$ Evolved During Denitration of Reprocessing Concentrate", pp. 118-31 in Denitration of Radioactive Liquid Waste, eds. L. Cecille and S. Halaszovich, Graham and Trotman, Norwell, Massachusetts, 1986.

14. J. L. Cox, M. A. Lilga, and R. T. Hallen, Thermochemical Nitrate Reduction, PNL-8226, Pacific Northwest Laboratories, Richland, Washington, September 1992.

15. J. M. Robinson et al., Destruction of Nivates, Organics, and Ferrocyanides By Hydrothermal Processing, LA-UR-93-456, Los Alamos National Laboratory, Los Alamos, New Mexico, 1993.

16. J. R. Berreth, Potential Calcining Stoichiometries and Their Effects On Waste Volumes, WINCO-1070, Idaho National Engineering Laboratory, Idaho Falls, Idaho, December 1989.

17. B. J. Newby, T. D. Thomson, and B. H. O'Brien, Calcination of Fluorinel-Sodium Waste Blends Using Sugar As a Feed Additive, WINCO-11879, Idaho National Engineering Laboratory, Idaho Falls, Idaho, June 1992.

18. A. J. Johnson and P. M. Amold, Waste Generation Reduction - Nitrates, Comprehensive Report of Denitrification Technologies, RFP-3899, Rockwell International, Golden, Colorado, March 1986.

19. D. E. Falk, E. J. Lahoda, and J. L. Mitchell, Nitrate Destruction By a Plasma Torch, FMPCSUB-020, Westinghouse Materials Company of Ohio, Cincinnati, Ohio, September 1988. 
DOEMWIP-10

\section{INTERNAL DISTRIBUTION}
1. T. Abraham
2. P. Backus
3. M. Baker
4-8. J. Berry
9. G. Bloom
10. C. Brown
11. A. Croff
12. T. Conley
13. R. Genung
14. B. Hightower

15. D. Hutchins

16. G. Kamp

17. T. Malinauskas

18. L. Mezga

19. J. Perona

20. M. Savage

21. P. Taylor

22. Central Research Library

23. Document Reference Center

24. ORNL Patent Section

25-26. ORNL Laboratory Records

27. ORNL Laboratory Records, RC

\section{EXTERNAL DISTRIBUTION}

28. N. Askew, Westinghouse Savannah River Co., P.O. Box 616, Aiken, SC 29802

29. C. Baldwin, EG\&G Rocky Flats, P.O. Box 464, Highway 93 \& Cactus, Bldg. 881, Golden, CO 80402-0464

30. M. Ballestri, BDM Federal, 20251 Century Blvd., 4th Floor, Germantown, MD 20874

31. J. Bassi, EM-351, U.S. Department of Energy, 12850 Middlebrook Road, Germantown, MD 20874

32. J. Batdorf, SAIC, 545 Shoup Ave., P.O. Box 50697, Idaho Falls, ID 83405-0697

33. S. Bates, EG\&G Idaho, Inc., P.O. Box 1625, MS-3930, Idaho Falls, ID 83415-3930

34. T. Bergsman, Battelle Pacific Northwest Laboratory, Battelle Boulevard, MS P7-41, Richland, WA 99352

35. L. Borduin, Los Alamos National Laboratory, One Bikini Road, MS K557, Los Alamos, NM 87545

36. M. Brooks, Waste Policy Institute, 555 Quince Orchard Blvd., Suite 600, Gaithersburg, MD 20879

37. H. Burns, Westinghouse Savannah River Co., P.O. Box 616, Bldg. 704-61s, Aiken, SC 29808

38. G. Bryan, Pacific Northwest Lab, Battelle, Blvd., Richland, VA 99352

39. P. Castel, U.S. DOE/HQ, WINCO, 20201 Century Blvd., Rm. 408, Germantown, MD 20874

40. D. Chaiko, Argonne National Lab, CMT/Bldg. 205, 9700 S. Cass Ave., Argonne, IL 60439

41. C. Collier, BDM Federal, 20251 Century Blvd., 4th Floor, Germantowin, MD 20874

42. C. Cooley, U.S. Department of Energy, FM-50, Trevion II, Washington, D.C. 20585-0002

43. T. Cooper, Westinghouse Hanford Corp., 2355 Stevens Dr., MS N3-12, Richland, WA 99352 
44. A. Corstillo, FERMCO, 25 Merchant St., 3rd Floor Technology, Springdale, OH 45246

45. S. Couture, Lawrence Livermore National Lab, P.O. Box 808, L-591, Livermore, CA 94551

46. G. Coyle, EM-541, U.S. Department of Energy, 12800 Middlebrook Road, Trevion II, Germantown, MD 20874-1290

47. P. Coyle, EM-55, U.S. Department of Energy, 19901 Germantown Road, Germantown, MD 20874

48. J. Cunnane, Argonne National Lab, 9700 South Cass Ave., Bldg, 205, Argonne, IL 60439

49. J. Dalton, SAIC, 545 Shoup Ave., P.O. Box 50697, Idaho Falls, ID 83405-0697

50. J. Dancz, SAIC, Quince Diamond Executive Center, 555 Quince Orchard Rd., Suite 500, Gaithersburg, MD 20878-4137

51. R. Darnell, EG\&G Idaho, Inc., P.O Box 1625, MS-3950, Idaho Falls, ID 834153950

52. L. Dewitt, SAIC, 545 Shoup Ave., P.O. Box 50697, Idaho Falls, ID 83405-0697

53. S. Domotor, U.S. DOE, EM-351, Trevion II, Washington, D.C. 20585

54. P. Erickson, EPA-RREL, 5995 Center Hill Ave., Cincinnati, OH 45224

55. J. Fannon, U.S. DOE, HQ/EM-50, 20201 Century Blvd., Bellmeade Bldg. II, Rm. 402, Germantown, MD 20874

56. G. Fitzgibbon, WHC, P.O. Box 1970, MS H6-07, Richland, WA 99352

57. C. Frank, EM-50, U.S. Department of Energy, Forrestal Office Building, Washington, DC 20585

58. E. Franz, Brookhaven National Lab, Environmental \& Waste Technology Center, North Railroad St., Bldg. 830, Upton, NY 11973

59. N. French, Sandia National Laboratory-Livermore, 7011 East Avenue, Livermore, CA 94550

60. M. Fuhrmann, Brookhaven National Laboratory, Building 703, Upton, NY 11973

61. A Gatuchette, US EPA, Risk Reduction Engineering Lab, 26 W. Martin Luther King Blvd., Cincinnati, OH 45268

62. R. Gehrke, EG\&G Idaho, Inc., 2151 N Blvd., MS-7111, P.O. Box 1625, Idaho Falls, ID 83415

63. R. Geimer, SAIC, 545 Shoup Ave., P.O. Box 50697, Idaho Falls, ID 83405-0697

64. R. Gillins, SAIC, 545 Shoup Ave., P.O. Box 50697, Idaho Falls, ID 83405-0697

65. K. Hain, EM-55, U.S. Department of Energy, 1000 Independence Ave., SW, Washington, DC 20585

66. T. Harris, SAIC, 545 Shoup Ave., P.O. Box 50697, Idaho Falls, ID 83405-0697

67. P. Hart, U.S. Department of Energy, EM-542, Trevion II, 19901 Germantown Rd., Germantown, MD 20874-0002

68. J. Helt, Argonne National Laboratory, 9700 S. Cass Avenue, Bldg. 205, Argonne, IL 60439

69. D. Helton, Westinghouse Savannah River Co., P.O. Box 616, Bldg. 773-41 A., Rm. 228, Aiken, SC 29802

70. B. Hickman, Lawrence Livermore National Lab, 7000 E. Ave., Livermore, CA 94550

71. D. Hjeresen, AET, MS-P641, Bikini Road, Los Alamos, NM 87545

72. J. Hunter, Westinghouse Hanford Co., P.O. Box 1970, MS L531, Bldg. 3766, Rm. 14, Richland, WA 99352

73. D. Isbell, EM-40, U.S. Department of Energy, 12800 Middlebrook Road, Trevion II, Germantown, MD 20874 
74. P. Jones, BDM Federal, 20251 Century Blvd., 4th Floor, Germantown, MD 20874

75. P. Kalb, Brookhaven National Lab, Environmental \& Waste Technology Center, North Railroad Street, Bldg. 830, Upton, NY 11973

76. T. Kan, Lawrence Livermore National Lab., P.O. Box 808, L-467, Livermore, CA 94550

77. B. Kitchen, Savannah River Laboratory, Westinghouse Savannah River Co., P.O. Box 616, Aiken, SC 29802

78. K. Kostelnik, EG\&G Idaho, Inc., P.O. Box 1625, MS-3930, Idaho Falls, ID 834153930

79. O. Kruger, Westinghouse Hanford Company, 2355 Stevens Dr., Richland, WA 99352

80. M. Lankford, EM-552, U.S. Department of Energy, 12800 Middlebriook Road, Trevion II, Germantown, MD 20874

81. M. Larsen, SAIC, 545 Shoup Ave., P.O. Box 50697, Idaho Falls, ID 83405-0697

82. G. Leatherman, SAIC, Quince Diamond Executive Center, 555 Quince Orchard Rd., Suite 500, Gaithersburg, MD 20878-0697

83. S. Lein, EM-54, U.S. Department of Energy, 12800 Middlebrook Road, Trevion II, Germantown, MD 20874-1290

84. J. Lippold, BDM Federal, 20251 Century Blvd., 4th Floor, Germantown, MD 20874

85. P. Lurk, EM-552, U.S. Department of Energy, 12800 Middlebrook Road, Trevion II, Germantown, MD 20874

86. J. Mayberry, SAIC, P.O. Box 50697, Idaho Falls, ID 83405-0697

87. W. McCulla, Los Alamos National Laboratory, SM 30 Warehouse, Bikini Road, MS J-563, Los Alamos, NM 87545

88. J. McFee, IT Corporation, 5301 Central Ave., NE, Albuquerque, NM 87108

89. K. Merrill, EG\&G Idaho, Inc., 2151 N Blvd., MS-3930, P.O. Box 1625, Idaho Falls, ID 83415

90. R. Moats, BDM International, 12850 Middlebrook Road, Suite 300, Germantown, MD 20874

91. J. Moore, U.S. Department of Energy, P.O. Box 2001, Oak Ridge, TN 37830-8620

92. D. Musgrave, Lawrence Livermore National Laboratory, 7000 East Avenue, P.O. Box 808, L-440, Livermore, CA 94550

93. T. Myrick, SAIC, P.O. Box 2501, Oak Ridge, TN 37831

94. R. Nakaoka, Los Alamos National Laboratory, P.O. Box 1663, MS-6517, Los Alamos, NM 87545

95. M. Nawar, Office of Radiation Programs, Environmental Protection Agency, 401 M St. SW, ANR-461, Washington, DC 20460

96. G. Ordaz, EM-541, U.S. Department of Energy, 12800 Middlebrook Road, Trevion II, Germantown, MD 20874

97. R. Peters, Battelle-Pacific Northwest Lab, P.O. Box 999, MS P7-41, Richland, WA 99352

98. W. Phillips, Roy F. Weston Office of Technology Services, 12850 Middlebrook Road, Germantown, MD 20874

99. W. Pitt, Texas A\&M University, Department of Nuclear Engineering, College Station, TX 77843

100. B. Place, Westinghouse Hanford Co., Solids \& Liquids Waste Remediation, P.O. Box 1970, MS H5-33, Richland, WA 99352

101. W. Ross, Battelle-Pacific Northwest Lab, P.O. Box 999, MS P7-41, Richland, WA 99352 
102. R. Schumacker, Westinghouse Savannah River Co., SRTC, P.O. Box 616, Bldg. 773-42A, Aiken, SC 29808

103. B. Schutte, EM-54, U.S. Department of Energy, 12800 Middlebrook Road, Trevion II, Germantown, MD 20874-1290

104. B. Schwinkendorf, BDM Federal, 1801 Randolph Rd., SE, Argonne, IL 60439

105. G. Sevigny, Battelle-Pacific Northwest Lab, P.O. Box 999, MSIN P7-42A, Aiken, SC 29808

106. M. Shupe, EM-541, U.S. Department of Energy, Trevion II, Room 440, 19901 Germantown Road, Germantown, MD 20874-1290

107. D. Singh, Argonne National Lab, 9700 South Cass Ave., Bldg. 212, Rm. G-233, Argonne, IL 60439

108. S. Slate, Battelle Pacific Northwest Laboratory, 902 Battelle Blvd., P.O. Box 999, KI-25, Richland, WA 99352

109. S. Stein, Battelle, Seattle Research Center, 4000 NE 41st, Seattle, WA 98105-5428

110. E. Steverson, SAIC, 545 Shoup Ave., P.O. Box 50697, Idaho Falls, ID 83405-0697

111. P. Sydenticker, BDM Federal, 20251 Century Blvd., 4th Floor, Germantown, MD 20874

112. H. Turner, ARCO, 2300 W. Plano Parkway, Plano TX, 75075-8499

113. T. Timmerman, Mason \& Hanger, Bldg. 11-2, P.O. Box 50697, Idaho Falls, ID 83405-0697

114. T. Uhlmeyer, MD-Ferguson Co., 7295 Highway 94 South, St Charles, MO 63304

115. J. Vavruska, Equinox, Ltd., 872 Don Cubero Ave., Santa Fe, NM 87501

116. C. Ward, Westinghouse Savannah River, Building 773-A, D-1134, Aiken, SC 29808

117. S. Warren, EM-442, U.S. Department of Energy, 12800 Middlebrook Road, Trevion II, Germantown, MD 20874-1290

118. J. Witzeman, P.O. Box 398704, 7400 Williey Road, Fernald, OH 45030

119. S. Wolf, U.S. Department of Energy, Trevion II, 19901 Germantown Road, Germantown, MD 20874

120. W. Wolfe, SAIC, 545 Shoup Ave., P.O. Box 50697, Idaho Falls, ID 83405-0697

121-122. A. Wollerman, Trevion I, 12850 Middlebrook Road, Suite 400, Room 721, Germantown, MD 20874

123. M. Zenkowich, EM-323, U.S. Department of Energy, 12800 Middlebrook Road, Germantown, MD 20874

124. Office of Assistant Manager, Energy Research and Development, DOE-OR, P.O. Box 2001, Oak Ridge, TN, 37831

125-126. Office of Scientific and Technical Information, P.O. Box 62, Oak Ridge, TN 37831 

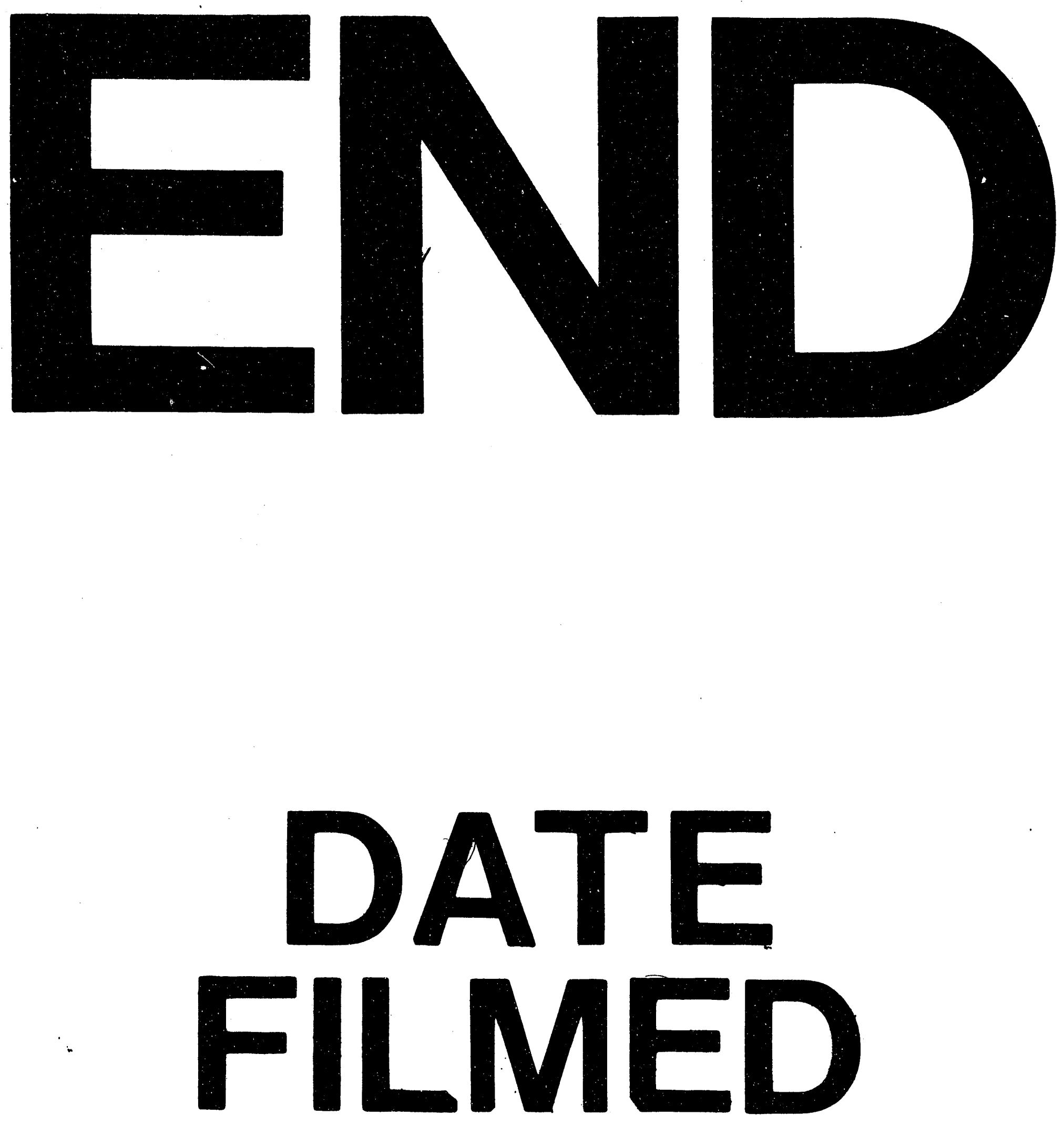

1

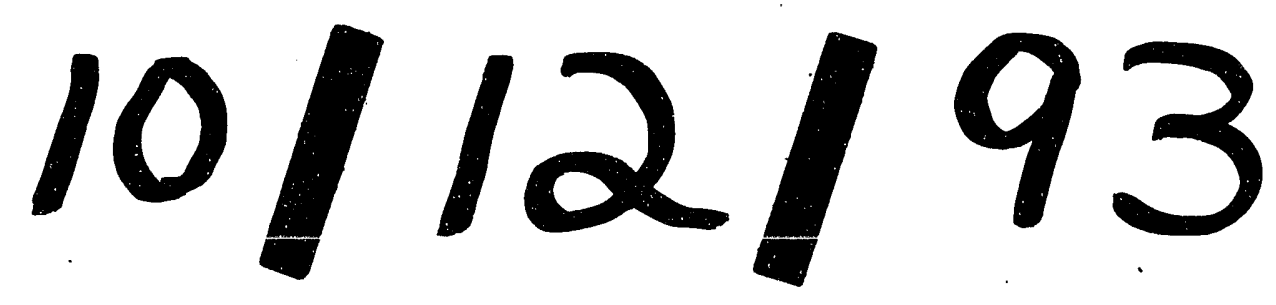


